\title{
Pengaruh Perbandingan Level Tepung Gamal (Gliricidia sepium) dan Tepung Lamtoro (Leucaena leucocephala) terhadap Kualitas Fisik Wafer sebagai Pakan Ternak Ruminansia Kecil
}

Adriana Soi

Fakultas Pertanian, Universitas Timor, Kefamenanu, TTU - NTT, 85613, Indonesia, email: adrianasoi936@ gmail.com

\section{Article Info}

\section{Article history:}

Received 19 Desember 2019

Received in revised form 21 Maret 2020 Accepted 10 April 2020

DOI:

https://doi.org/10.32938/ja.v5i2.932

\section{Keywords:}

Kerapatan wafer

Kadar air

Warna wafer

Aroma wafer

\section{Abstrak}

Tersedianya pakan ternak yang cukup jumlahnya maupun mutunya dan berkesinambungan merupakan salah satu faktor yang menentukan keberhasilan pengembangan ternak ruminansia. Salah satu pengolahan pakan yang dapat dibuat adalah membuat wafer. Wafer merupakan salah satu teknologi pengolahan pakan yang efektif dan diharapkan dapat menjaga kontinuitas ketersediaan pakan terutama pada musim kemarau. Tujuan dari penelitian ini adalah untuk mengetahui kualitas fisik wafer yang dibuat dengan perbandingan level tepung gamal dan tepung lamtoro sebagai pakan ternak ruminansia kecil. Variabel yang diukur dalam penelitian ini adalah kerapatan wafer, kadar air, warna dan aroma. Bahan yang digunakan dalam penelitian ini adalah tepung gamal, tepung lamtoro, dedak halus, tepung jagung, mineral mix, tepung kanji, air. Metode yang digunakan adalah Rancangan Acak Lengkap dengan variasi perlakuan sebagai berikut: R1= Tepung Gamal 20\% + Tepung Lamtoro $60 \%$ + Dedak halus Jagung $8 \%$ + Mineral mix $2 \%$, R2= Tepung Gamal $40 \%+$ Tepung Lamtoro $40 \%$ + Dedak halus $10 \%+$ Jagung $8 \%+$ Mineral mix 2\%, R3 = Tepung Gamal 60\% + Tepung Lamtoro $20 \%+$ Dedak halus $10 \%$ + Jagung $8 \%$ + Mineral mix 2\%, R4=Tepung Gamal 80\% + Tepung Lamtoro 0\% + Dedak halus 10\% + Jagung $8 \%+$ Mineral mix 2\%. Disimpulkan bahwa pembuatan wafer untuk ternak ruminansia kecil dengan perbandingan level tepung gamal dan level tepung lamtoro menghasilkan nilai kerapatan yang berbeda. Kerapatan tertinggi pada perbandingan $40 \%$ tepung gamal dan $40 \%$ tepung lamtoro (R2) yaitu $0,41 \mathrm{~g} / \mathrm{cm}^{3}$, sedangkan nilai kadar air, warna dan aroma adalah sama untuk semua perlakuan.

\section{Pendahuluan}

Keberhasilan usaha ternak ruminansia tidak terlepas dari masalah ketersediaan pakan khususnya pakan hijauan. Tersedianya pakan ternak yang cukup jumlahnya maupun mutunya dan berkesinambungan, merupakan salah satu faktor yang menentukan keberhasilan pengembangan ternak ruminansia tersebut. Salah satu alternatif yang dapat dimanfaatkan adalah menggunakan hijauan leguminosa pohon terutama tanaman gamal sebagai pakan alternatif.

Gamal merupakan salah satu jenis tanaman yang dapat digunakan sebagai sumber hijauan untuk pakan ternak ruminansia. Tanaman in merupakan tanaman berbentuk pohon dan dapat tumbuh dengan baik di daerahdaerah sampai ketinggian $1.300 \mathrm{~m}$ di atas permukaan laut, juga dapat tumbuh pada tanah yang kurang subur dan tahan terhadap musim kemarau yang panjang. Gamal banyak dijumpai dan tersebar luas di seluruh pelosok tanah pedesaan dan mudah tumbuh hampir di semua tempat.

Gamal merupakan tanaman pakan ternak yang baik karena kemampuan produksinya tinggi dan kualitas hijauannya yang baik. Gamal merupakan pakan ternak sumber protein yang baik dengan kandungan protein yang lebih tinggi dari pada konsentrat yang memiliki kandungan protein maksimal hanya $17 \%$. Daun gamal dapat diberikan pada ternak ruminansia sebagai makanan tunggal atau campuran dengan rumput. Daun gamal segar biasanya kurang disukai ternak karena bau yang tidak sedap. Hal tersebut karena ada aroma khas yang terdapat pada daun gamal yaitu kandungan komarin. Komarin dapat dikurang dengan cara pengolahan, untuk mempertahankan kualitas dengan tingkat palatabilitas tinggi, lebih efisien dalam penyimpanan dan efektif dalam pemberian. Selain tanaman gamal, tanaman lamtoro juga merupakan salah satu jenis leguminosa pohon yang dapat berfungsi sebagai hijauan makanan ternak, dengan kandungan protein kasarnya 24,4\% (Jelantik, 2001). Salah satu pengolahan pakan yang dapat dibuat adalah membuat wafer. Wafer merupakan salah satu teknologi pengolahan pakan yang efektif dan diharapkan dapat menjaga kontinuitas ketersediaan pakan terutama pada musim kemarau.

Kana Hau et al. (2004) melaporkan bahwa pemberian wafer gamal pad ternak sapi bali terjadi peningkatan bobot badan sebesar $0,09 \mathrm{~kg} / \mathrm{ekor} / \mathrm{hari}$, sedangkan pemberian wafer lamtoro terjadi peningkatan bobot badan ternak sapi sebesar 0,23 kg/ekor/hari. Jayusmar (2000) menyatakan wafer ransum komplit adalah suatu produk pengolahan pakan ternak yang terdiri dari pakan sumber serat yaitu hijauan dan konsentrat dengan komposisi yang seimbang berdasarkan kebutuhan nutrisi ternak dan dalam proses pembuatannya mengalami pemadatan. Wafer ransum komplit yang terdiri dari campuran hijauan dan konsentrat dapat meningkatkan efisiensi penggunaan pakan karena ternak tidak dapat memilih antara pakan hijauan dan konsentrat, berdasarkan hal tersebut diharapkan dapat mencukupi kebutuhan nutrisinya.

Untuk menjaga kebutuhan nutrisi, maka terlebih dahulu harus memperhatikan kualitas fisik dari pakan wafer tersebut. Kualitas fisik merupakan bagian dari karakteristik mutu yang berhubungan dengan nilai kepuasan konsumen terhadap bahan. Sifat-sifat bahan serta perubahanperubahan yang terjadi pada pakan dapat digunakan untuk menilai dan menentukan mutu pakan. Selain itu pengetahuan tentang kualitas fisik digunakan juga untuk menentukan keefisienan suatu proses penanganan, pengolahan dan penyimpanan (Nursita, 2005). Kerapatan pakan wafer merupakan salah satu karakteristik fisik yang sangat mempengaruhi penampilan wafer, penanganan transportasi dan mengefisienkan ruang penyimpanan. Kerapatan wafer yang tinggi secara fisik memudahkan dalam penanganan baik penyimpanan maupun guncangan pada saat transportasi dan diperkirakan akan lebih tahan lama dalam penyimpanan karena bentuk fisiknya yang padat dan keras. Kadar air merupakan faktor yang sangat penting dalam penentuan kualitas pakan, karena terkait dengan nilai nutrisi dan daya simpan. Bahan pakan yang memiliki kadar air tinggi, maka persentase nilai nutrisinya semakin rendah dan daya simpannya relatif lebih singkat, hal ini dikarenakan bahan pakan tersebut akan mudah terserang jamur, sehingga kualitas pakan menurun dan dapat mengakibatkan keracunan bagi ternak. Aroma dan warna merupakan salah satu pengujian kualitas fisik pakan yang dapat dijadikan pedoman dalam menentukan mutu produk pakan itu sendiri.

\section{Metode}

\subsection{Waktu dan Lokasi Penelitian}

Penelitian ini dilaksanakan di Fakultas Pertanian Universitas Timor, Kefamenanu dan berlangsung selama 1 bulan terhitung dari bulan Mei sampai Juni 2019

\subsection{Alat dan Bahan}

Alat yang di gunakan adalah : Cetakan wafer, timbangan analitik, cawan, plastik, penggaris, spidol, pisau, ember, dan alat tulis. Bahan yang digunakan dalam penelitian ini adalah : tepung gamal, tepung lamtoro, dedak halus, tepung jagung, tepung kanji, mineral mix, air.

\subsection{Metode Penelitian}

Metode penelitian yang di gunakan adalah Rancangan Acak Lengkap (RAL) dengan 4 perlakuan dengan 5 ulangan, rancangan percobaan yang di gunakan adalah:

R1: Tepung Gamal 20\% + Tepung Lamtoro 60\% + Dedak halus 10\% + Jagung $8 \%+$ Mineral mix $2 \%$

R2: Tepung Gamal $40 \%$ + Tepung Lamtoro $40 \%$ + Dedak halus 10\% + Jagung $8 \%$ + Mineral mix $2 \%$

R3: Tepung Gamal 60\% + Tepung Lamtoro 20\% + Dedak halus 10\% + Jagung $8 \%+$ Mineral mix $2 \%$

R4: Tepung Gamal 80\% + Tepung Lamtoro 0\% + Dedak halus 10\% + Jagung $8 \%+$ Mineral mix $2 \%$

Tabel 1. Kandungan nutrisi bahan pakan wafer

\begin{tabular}{lcccc}
\hline \multirow{2}{*}{ Nutrisi } & \multicolumn{4}{c}{ Bahan pakan } \\
\cline { 2 - 5 } & Gamal & Lamtoro & Dedak halus & Jagung \\
\hline Bahan kering (\%) & 27,0 & 25,4 & 88,2 & 88,0 \\
Abu (\%) & 9,7 & 7,6 & 12,28 & 2,41 \\
Protein kasar (\%) & 19,1 & 24,35 & 9,80 & 10,82 \\
Serat kasar (\%) & 18,0 & 22,1 & 15,86 & 3,37 \\
Lemak kasar (\%) & 3,0 & 3,68 & 4,81 & 5,89 \\
Beta-N & 50,2 & 42,2 & 45,80 & 77,49 \\
Ca & 0,67 & 1,68 & 0,09 & 0,05 \\
P & 0,19 & 0,22 & 1,09 & 0,31 \\
\hline
\end{tabular}

\subsection{Prosedur Pembuatan Wafer}

1. Mempersiapkan alat dan bahan yang digunakan

2. Daun gamal dan lamtoro dipotong dan dikeringkan di bawah sinar matahari

3. Bahan-bahan yang sudah dikeringkan dibuat menjadi tepung

4. Mencampur tepung kanji, tepung gamal, tepung lamtoro, tepung jagung, dedak padi, mineral mix sesuai dengan persentase perlakuan.

5. Kemudian mencetak campuran bahan tersebut menggunakan alat pencetak wafer, ukuran sesuai alat pencetak.

6. Setelah itu dimasukkan ke dalam oven.

\subsection{Variabel Penelitian}

Variabel yang diukur dalam penelitian ini adalah :

2.5.1 Kerapatan Wafer

Contoh uji ditimbang beratnya dan diukur panjang, lebar dan tebalnya. Perhitungan menggunakan rumus : 
Kerapatan $\left(\mathrm{g} / \mathrm{cm}^{3}\right)=\frac{\mathrm{W}}{\mathrm{PxT} \mathrm{TL}}$

Keterangan :

$\mathrm{W}=$ Berat contoh uji $(\mathrm{g})$

$\mathrm{P}=$ Panjang contoh uji $(\mathrm{cm})$

$\mathrm{L}=$ Lebar contoh uji $(\mathrm{cm})$

$\mathrm{T}=$ Tebal contoh uji $(\mathrm{cm})$

\subsubsection{Kadar Air}

Perhitungan kadar air dihitung dengan rumus :

kadar $\operatorname{air}(\%)=\frac{b-c}{b-a} \times 100 \%$

Keterangan:

$\mathrm{a}=$ berat cawan kosong $(\mathrm{g})$

$\mathrm{b}=$ berat cawan + sampel wafer $(\mathrm{g})$

$\mathrm{c}=$ berat cawan + sampel wafer setelah di oven hingga beratnya konstan $(\mathrm{g})$

\subsubsection{Warna}

Penentuan warna berdasarkan skor1-3 yaitu :

1. Coklat sampai hitam

2. Hijau gelap atau kuning kecokelatan

3. Hijau alami atau hijau kekuningan

\subsubsection{Aroma (skor 1-3)}

Penentuan aroma wafer berdasarkan skor1-3 yaitu :

1. Kurang harum

2. Agak harum

3. Harum

\subsection{Analisis Data}

Data yang diperoleh dianalisis menggunakan sidik ragam (Anova) sesuai Rancangan Acak Lengkap (RAL) dengan 4 perlakuan dan 5 ulangan dan dilanjutkan dengan uji duncan. Analisis data menggunakan program SPSS versi 19.0.

\section{Hasil dan Pembahasan}

\subsection{Kerapatan Wafer}

Rataan kerapatan wafer pada $\mathrm{R} 1=0,39 ; \mathrm{R} 2=0,41 ; \mathrm{R} 3=0,36 ; \mathrm{R} 4=0,37$

(Tabel 1). Hasil uji statistik menunjukkan bahwa pengaruh perbandingan tepung gamal dan tepung lamtoro berbeda nyata $(\mathrm{P}<0,05)$ terhadap kerapatan wafer.

Tabel 2. Nilai rataan kerapatan pakan wafer perbandingan level tepung gamal dan tepung lamtoro.

\begin{tabular}{ccccccc}
\hline \multirow{2}{*}{ Perlakuan } & \multicolumn{5}{c}{ Ulangan } & \multirow{2}{*}{ Rataan } \\
\cline { 2 - 5 } & 1 & 2 & 3 & 4 & 5 & \\
\hline $\mathrm{R} 1$ & 0,37 & 0,4 & 0,39 & 0,42 & 0,37 & $0,39^{\mathrm{ab}}$ \\
$\mathrm{R} 2$ & 0,42 & 0,4 & 0,41 & 0,41 & 0,39 & $0,41^{\mathrm{a}}$ \\
$\mathrm{R} 3$ & 0,36 & 0,34 & 0,39 & 0,34 & 0,38 & $0,36^{\mathrm{c}}$ \\
$\mathrm{R} 4$ & 0,38 & 0,36 & 0,37 & 0,38 & 0,36 & $0,37^{\mathrm{bc}}$ \\
\hline \multicolumn{1}{l}{ Ket $:$ Superskrip yang berbeda pada nilai rataan menunjukkan perbedaan nyata $(P<0,05)$}
\end{tabular}

Pada Tabel 2 menunjukkan bahwa perlakuan R2 memiliki rataan nilai kerapatan paling tinggi yaitu $\left(0,41 \mathrm{~g} / \mathrm{cm}^{3}\right)$, sedangkan perlakuan $\mathrm{R} 3$ memiliki rataan nilai kerapatan paling rendah yaitu $\left(0,36 \mathrm{~g} / \mathrm{cm}^{3}\right)$. Hasil uji statistik menunjukkan bahwa ada pengaruh yang nyata perbandingan level tepung gamal (Gliricidia sepium) dan tepung lamtoro (Leucaena leucocephala) terhadap kualitas fisik wafer sebagai pakan ternak ruminansia kecil. Sedangkan uji lanjut menunjukkan bahwa R2 berbeda dengan R3 dan R4 namun tidak berbeda dengan R1, R1 dan R4 tidak berbeda namun berbeda dengan R2 dan R3, R1 berbeda dengan R3 namun tidak berbeda dengan R2 dan R4.

Perlakuan terbaik dalam penelitian ini adalah pada perlakuan R2 yang menunjukkan nilai kerapatan tertinggi di antara perlakuan lainnya. Hal ini disebabkan karena pada perlakuan ini memiliki kadar air rendah. Semakin tinggi nilai kerapatan maka daya simpan wafer akan lebih tahan lama. Dijelaskan oleh Daud et al. (2013) bahwa kerapatan wafer semakin tinggi diperkirakan akan lebih tahan lama dalam penyimpanan karena bentuk fisiknya yang padat dan keras, selain itu secara fisik juga akan lebih mudah dalam penanganan baik dalam penyimpanan atau adanya guncangan pada saat transportasi.

Terjadinya penurunan nilai kerapatan pakan wafer pada perlakuan R3, disebabkan karena tingginya serat kasar pada perlakuan tersebut. Semakin tinggi kadar serat maka semakin rendah kerapatan atau bahan tersebut semakin amba (Toharmat et al., 2006). Kerapatan pakan wafer yang rendah akan memperlihatkan bentuk pakan wafer yang tidak terlalu padat dan tekstur yang lebih lunak serta porous (berongga), sehingga menyebabkan terjadinya sirkulasi udara dalam tumpukan selama penyimpanan dan diperkirakan hanya dapat bertahan dam waktu yang singkat (Jayusmar, 2000).

\subsection{Kadar Air}

Kadar air merupakan faktor yang sangat penting dalam penentuan kualitas pakan, karena terkait dengan nilai nutrisi dan daya simpan. Berdasarkan Tabel 3 dapat diketahui bahwa rataan nilai kadar air pakan wafer pengaruh perbandingan level tepung gamal dan tepung lamtoro, perlakuan R3 $(14,95)$ lebih tinggi dari perlakuan R1, R2 dan R4 dan nilai kadar air terendah terdapat pada perlakuan R2 (14,52). Hasil uji statistik menunjukkan bahwa perlakuan berpengaruh tidak nyata terhadap kadar air wafer. Nilai rataan kadar air pakan wafer pada setiap perlakuan tercantum pada Tabel 3 .

Tabel 3. Rataan kadar air pakan wafer perbandingan level tepung gamal dan tepung lamtoro.

\begin{tabular}{ccccccc}
\multirow{2}{*}{ Perlakuan } & \multicolumn{5}{c}{ Ulangan } & \multirow{2}{*}{ Rataan } \\
\cline { 2 - 5 } & 1 & 2 & 3 & 4 & 5 & \\
\hline R1 & 15,02 & 14,01 & 15,62 & 13,58 & 14,48 & 14,54 \\
R2 & 12,93 & 14,73 & 12,96 & 17,09 & 14,88 & 14,52 \\
R3 & 14,81 & 14,96 & 15,72 & 12,32 & 15,16 & 14,59 \\
R4 & 13,02 & 13,17 & 15,3 & 14,95 & 16,41 & 14,57 \\
\hline
\end{tabular}

Nilai kadar air pada perlakuan R3 tinggi karena pada saat pembuatan pakan wafer tidak terlalu padat pada saat pengempaan, membuat pakan wafer berongga sehingga daya serap airnya tinggi, dan juga banyaknya penggunaan bahan perekat pada saat pembuatan pakan wafer. Pakan wafer dengan kemampuan daya serap air tinggi akan berakibat akan terjadinya mengembang yang tinggi pula, karena semakin banyak volume air hasil penyerapan yang tersimpan dalam pakan wafer akan diikuti dengan peningkatan perubahan muai wafer (Retnani et al., 2009).

Pakan wafer dengan kandungan kadar air yang tinggi akan cepat membusuk sehingga masa simpannya tidak lama. Pakan wafer yang akan terserang jamur lebih cepat adalah yang memiliki kadar air yang tinggi. Peningkatan kadar air mengakibatkan ketidakstabilan tekstur wafer sehingga permukaan bahan menjadi kondusif untuk pertumbuhan dan kerusakan mikrobial (Retnani et al., 2009). Perlakuan R2 merupakan perlakuan yang memiliki kadar air terendah yang disebabkan karena memiliki bahan penyusun pakan wafer dan kombinasi antara tepung gamal dan tepung lamtoro dengan persentase yang sama. Trisyulianti et al. (2001) aktivitas mikroorganisme dapat ditekan pada kadar air $12 \%-14 \%$, sehingga bahan pakan tidak mudah berjamur dan membusuk.

\subsection{Warna wafer}

Warna pakan wafer merupakan salah satu parameter untuk menentukan kualitas fisik. Berdasarkan Tabel 3 menunjukkan bahwa rataan skor warna pakan wafer pada R1, R2, R3 dan R4 berturut-turut adalah 2,45; 2,55; 2,55;dan 2,65 atau menunjukkan warna hampir hijau alami atau hijau kekuningan. Analisis statistik menunjukkan bahwa perbandingan level tepung gamal dan tepung lamtoro berpengaruh tidak nyata terhadap warna wafer.

\begin{tabular}{ccccccc}
\multicolumn{7}{l}{ Tabel 4. Nilai rataan warna wafer } \\
\cline { 2 - 5 } Perlakuan & 1 & 2 & 3 & 4 & 5 & \multirow{2}{*}{ Rataan } \\
\cline { 2 - 6 } & 2,50 & 2,50 & 2,37 & 2,37 & 2,50 & 2,45 \\
R1 & 2,50 & 2,62 & 2,37 & 2,50 & 2,75 & 2,55 \\
R2 & 2,75 & 2,37 & 2,50 & 2,75 & 2,37 & 2,55 \\
R3 & 2,75 & 2,75 & 2,50 & 2,75 & 2,50 & 2,65 \\
R4 &
\end{tabular}

Dari 4 perlakuan, warna yang dihasilkan tidak jauh berbeda namun secara numerik perlakuan R4 lebih menunjukkan warna wafer yang hampir mendekati hijau alami. Hal ini disebabkan karena pada perlakuan ini menggunakan tepung gamal lebih banyak yaitu $(80 \%)$ sedangkan penggunaan tepung lamtoro $(0 \%)$. Warna wafer yang dihasilkan dalam penelitian ini sama dengan warna wafer ransum komplit tanaman ubi kayu dengan lama penyimpanan berbeda yang dihasilkan oleh Shodik (2018) yang berkisar 2,582,73 atau memiliki warna coklat muda dan sedikit lebih tinggi dari laporan Sholihin (2015) yang membuat wafer berbahan limbah sayuran dan umbiumbian dengan nilai $1,68-2,72$.

\subsection{Aroma Wafer}

Rataan nilai aroma yang diperoleh dari Tabel 4 diketahui bahwa perlakuan R1, R2, R3 dan R4 berturut-turut yaitu 2,80; 2,78; 2,73 dan 2,90. Hasil analisis statistik menunjukkan bahwa untuk semua perlakuan berpengaruh tidak nyata serta cenderung menunjukkan aroma yang hampir sama.

\section{Tabel 5. Nilai rataan aroma wafer}

\begin{tabular}{ccccccc}
\multirow{2}{*}{ Perlakuan } & \multicolumn{5}{c}{ Ulangan } & \multirow{2}{*}{ Rataan } \\
\cline { 2 - 5 } & 1 & 2 & 3 & 4 & 5 & \\
\hline R1 & 3,00 & 2,63 & 3,00 & 2,63 & 2,75 & 2,80 \\
R2 & 2,88 & 2,75 & 2,88 & 2,63 & 2,75 & 2,78 \\
R3 & 2,63 & 2,88 & 2,75 & 2,88 & 2,5 & 2,73 \\
R4 & 2,88 & 2,88 & 3,00 & 2,88 & 2,88 & 2,90 \\
\hline
\end{tabular}

Data pada Tabel 5, menunjukkan bahwa nilai rataan terhadap aroma wafer yang dibuat dengan perbandingan tepung gamal dan tepung lamtoro berkisar 2,73-2,90 atau beraroma hampir harum. Aroma pakan wafer yang baik adalah pakan yang beraroma harum. Aroma pakan yang segar akan meningkatkan konsumsi oleh ternak (Utomo, 2010). Faktor yang mempengaruhi aroma pakan wafer yaitu bahan baku, lama penyimpanan dan 
kandungan nutrisi dalam pakan wafer. Nilai aroma yang dihasilkan dari penelitian ini sama juga dengan nilai aroma yang dilaporkan Solihin (2015), yakni berkisar 1,82-2,97 dengan aroma harum khas wafer. Hal ini disebabkan oleh aktivitas mikroorganisme.

\section{Simpulan}

Disimpulkan bahwa pembuatan wafer untuk ternak ruminansia kecil dengan perbandingan level tepung gamal dan tepung lamtoro yang berbeda menghasilkan nilai kerapatan yang berbeda. Kerapatan tertinggi pada perbandingan $40 \%$ tepung gamal dan $40 \%$ tepung lamtoro (R2) yaitu 0,41 $\mathrm{g} / \mathrm{cm}^{3}$, sedangkan nilai kadar air, warna dan aroma adalah sama untuk semua perlakuan.

\section{Pustaka}

Daud, M., Z. Fuadi, dan Azwis. 2013. Uji Fisik dan Daya Simpan Wafer Ransum Komplit Berbasis Kulit Buah Kakao. Jurnal Ilmiah Peternakan, 1 (1) : 20-22.

Jayusmar.2000. Pengaruh Suhu dan Tekanan Pengempaan Terhadap Sifat Fisik Wafer Ransum Komplit dari Limbah Pertanian Sumber Serat dan Leguminosa untuk Ternak Ruminansia. Fakultas Peternakan. Institut Pertanian Bogor. Bogor.

Jelantik. I.G.N. 2001. Improving Bali Cattle (Bibos banteng wagner) Production Through Protein Supplementation. Ph.D. Thesis. Department of Animal Science and Animal Health The Royal Veterinary and Agricultural University Copenhagen. Denmark.

Kana Hau.D.. Nullik. J.. Laigo. O.T..Liem.C. 2004.Pemanfaatan Pakan Awet Pada Ternak Sapi Bali Timor.Laporan Hasil Penelitian BPTP NTTNaibonat.

Nursita. 2005. Sifat Fisik dan Palatabilitas Wafer Ransum Komplit untuk Domba dengan menggunakan Kulit Singkong. Skripsi. Bogor: Fakultas Peternakan. Institut Pertanian Bogor.

Retnani., S. Basymeleh dan L. Herawaty. 2009. Pengaruh Jenis Hijauan Pakan dan Lama Penyimpanan Terhadap Sifat Fisik Wafer. Jurnal Ilmiah IlmuIlmu Peternakan, 12 (4) :196-202..

Shodik, M. 2018. Sifat fisik wafer ransum komplit berbasis limbah tanaman ubi kayu (Manihot utilissima) dengan lama penyimpanan berbeda. Skripsi. Universitas Islam Negeri Sultan Syarif Kasim Riau. Pekanbaru.

Solihin., Muhtarudin dan R .Sutrisna.2015.Pengaruh Lama Penyimpanan terhadap Kadar Air Kualitas Fisik dan Sebaran Jamur Wafer Limbah Sayuran dan Umbi-Umbian. Jurnal Ilmiah Peternakan Terpadu, 3 (2) : 48-54

Toharmat, T., E. Nursasih, R. Nazilah, N. Hotimah, T.Q. Noerzihad, N.A. Sigit, \& Y. Retnani. 2006. Sifat fisik pakan kaya serat dan pengaruhnya terhadap konsumsi dan kecernaan nutrien ransum pada kambing. Med. Pet, 29(1): 146-154.

Trisyulianti, E., Suryahadi \& V. N. Rakhma.2003. Pengaruh Penggunaan Molases dan Tepung Gaplek Sebagai Bahan Perekat Terhadap Sifat Fisik Wafer Ransum Komplit. Media Peternakan, 26: 35-40.

Utomo, A. J. 2010. Palatabilitas Serta Rasio Konsumsi Pakan dan Air Minum Kelinci Jantan Lokal Peranakan New Zealand White yang diberi Pellet atau Silase Ransum Komplit. Skripsi. Institut Pertanian Bogor, Bogor. 